\title{
KAJIAN EFISIENSI PEMANFAATAN KAYU MERBAU DAN RELOKASI INDUSTRI PENGOLAHANNYA \\ Bagian 1: Propinsi Papua Sebagai Penghasil Kayu Merbau dan Tujuan Relokasi
}

\section{Evaluation on Utilization Efficiency of Merbau and Relocation of its Wood Industry \\ Part 1: A Case Study in Papua Province as Merbau Wood Resource and Destination of Relocation}

\author{
Oleh / By : \\ Jamaludin Malik, Osly Rachman, Jamal Balfas dan Achmad Supriadi ${ }^{1)}$
}

\begin{abstract}
The processing of Merbau wood (Intsia spp.) has become an important issue as Papua Province asked the Central Government for log export dispensation. However, in order to keep the value added of the log, Indonesian Government through Presidential Decree No. 7, 2002 offered industries that handling Merbau's wood to relocate from East Java to Papua.

In the aim of evaluating objective condition of wood merbau utilization and merbau wood based industries relocation urgency, The comprehensive study has to be done on raw material potency, recent log distribution, relevant regulation and labour involved in industries. The study is divided into two parts. Part one of this study focused on recent condition in Papua, includes data collecting of merbau wood potency and reviewing merbau wood industries. While, the second part, which will publish in different paper, concerning about merbau wood industries in East Java that will be relocated.

The result of part one study shows that merbau's potency in Papua is large. The potency is about 2.662 million $\mathrm{m}^{3} /$ year from natural forest. The wood industries in Papua is relatively sufficient for merbau wood utilization. The industries contain 9 large wood mills and 66 units of small-medium scale wood-mills, which process merbau wood. Mostly, they sawed merbau wood into sawn timber type S2S and S4S. It is also noted, that there are a lot of small sawmill in forest area that saws merbau wood into balken using chainsaw. In fact, the industries in Papua lacks of merbau wood as raw material. Based on evaluation, it can be concluded that the relocation of merbau wood industry is not sufficient alternative. Merbau wood still can be utilized by local industry. The important thing to do is improving the technical ability of local industry to increase wood yield and improvement of merbau wood products marketing.
\end{abstract}

Keywords: Merbau wood, utilization, industry, relocation, Papua

\footnotetext{
1) Peneliti pada Pusat Penelitian dan Pengembangan Hasil Hutan, Bogor
} 


\begin{abstract}
ABSTRAK
Kayu Merbau (Intsia spp.) pernah menjadi isu penting karena Pemerintah Propinsi Papua meminta dispensasi dari Pemerintah Pusat untuk mengekspor log kayu tersebut. Argumentasi yang dikemukakan adalah kekerasan kayu tersebut, sehingga tidak bisa diolah di dalam negeri. Apabila tidak diekspor berarti sumberdaya alam yang dimiliki Propinsi Papua tidak dimanfaatkan secara optimal untuk pembangunan daerah. Sementara itu, Inpres No. 7 tahun 2002 menawarkan paket relokasi industri dari wilayah Jawa Timur ke Papua.

Untuk mengevaluasi kondisi obyektif pemanfaatan kayu merbau dan urgensi relokasi industrinya, dilakukan kajian ilmiah komprehensif yang meliputi potensi bahan baku, alokasi penggunaan, tenaga kerja dan peraturan yang terkait dengan pemanfaatan kayu merbau. Tulisan ini dibagi menjadi dua bagian. Bagian pertama, kajian difokuskan terhadap wilayah Papua sebagai sumber bahan baku dan tempat tujuan relokasi industri pengolahan kayu merbau, mencakup pengumpulan data dilakukan melalui observasi dan wawancara dengan instansi terkait di wilayah Jakarta, Banten dan Papua. Bagian kedua akan disajikan pada tulisan terpisah, yang akan mengkaji industri kayu merbau di Jawa Timur dan sekitarnya yang akan direlokasi.

Hasil observasi di Papua diketahui bahwa potensi kayu merbau yang dapat dimanfaatkan masih cukup besar, yaitu 2,662 juta $\mathrm{m}^{3} /$ tahun. Untuk menunjang pengelolaan hutan lestari, perlu dilakukan perhitungan ulang atas potensi kayu. Di Papua terdapat 9 industri besar yang mengolah kayu merbau dan 66 unit industri kecil/menengah yang mengalami kekurangan bahan baku kayu merbau. Sebagian besar industri mengolah kayu merbau menjadi kayu gergajian, S2S dan S4S. Banyak kilang penggergajian kecil di areal hutan menggergaji kayu bulat merbau menjadi balok kasar dengan menggunakan gergaji rantai. Evaluasi terhadap data dan informasi yang tersedia dapat disimpulkan bahwa relokasi industri bukan merupakan alternatif yang tepat. Pembinaan yang lebih tepat adalah peningkatan kemampuan teknis industri dan pemasaran kayu merbau di Papua, sehingga mampu memproduksi barang jadi (finished products) dan langsung dapat memasarkannya.
\end{abstract}

Kata kunci: Kayu merbau, pemanfaatan, relokasi, industri, Papua

\title{
I. PENDAHULUAN
}

Di Indonesia terdapat banyak jenis pohon yang selama puluhan tahun diabaikan di hutan dengan alasan tidak disukai pasar atau memiliki kelemahan sifat kayunya. Salah satu jenis yang sebelumnya dianggap kurang penting penggunaannya adalah merbau (Intsia sp). Kayu merbau adalah salah satu jenis yang pemanfaatannya masih dianggap kurang intensif di Indonesia, dalam arti volume penggunaan relatif kecil dibandingkan dengan potensinya (Soerianegara dan Lemmens, 2002). Diperkirakan jenis ini memiliki potensi cukup besar terutama di daerah produksi utama Papua. Merbau termasuk kayu berat dan keras yang memiliki beberapa keunggulan diantara kelemahan sifat-sifat kayunya, antara lain kayu ini agak sulit dikeringkan.

Pada tahun 1992 dari daerah Papua pernah diproduksi sekitar 121.000 m3/tahun (Soerianegara dan Lemmens, 2002). Pada tahun 2002 kayu merbau menjadi isu penting pada tingkat DPR-RI karena Pemerintah Propinsi Papua meminta dispensasi dari Pemerintah Pusat untuk diperbolehkan mengekspor log kayu tersebut terlepas dari adanya peraturan yang melarang ekspor log. Argumentasi yang dikemukakan adalah kayu merbau tidak bisa diolah di dalam negeri, khususnya di Papua. Apabila tidak diekspor berarti sumberdaya alam yang dimiliki Propinsi Papua tidak dimanfaatkan secara optimal untuk pembangunan daerah. Pada sisi lain, Pemerintah Pusat menawarkan alternatif relokasi industri kayu merbau dari Jawa Timur ke Papua melalui Inpres No. 7 tahun 2002 tentang Strategi Nasional Percepatan Pembangunan Kawasan Timur Indonesia dengan Program Pengembangan Pengelolaan Sumberdaya Hutan. Namun demikian, Pemerintah Propinsi Papua masih menginginkan ekspor kayu gelondongan dan tidak menghendaki adanya relokasi. Hal 
ini menunjukkan adanya dua keinginan yang berlainan dalam pemanfaatan kayu merbau. Untuk menanggulangi permasalahan tersebut diperlukan suatu kajian ilmiah yang dapat mengungkap permasalahan dan solusi secara obyektif, yang mencakup aspek teknis, ekonomis, sosial serta legalitas pemanfaatan kayu merbau. Tulisan yang terdiri dari dua bagian ini, menyajikan hasil kajian terhadap permasalahan industri kayu merbau serta evaluasi terhadap kemungkinan relokasi kayu merbau dari Jawa ke Papua. Bagian pertama, mengemukakan hasil kajian terhadap Papua sebagai daerah penghasil kayu merbau dan daerah tujuan relokasi. Bagian kedua akan difokuskan pada keadaan industri kayu merbau di Jawa sebagai daerah asal industri yang akan direlokasi.

\section{BAHAN DAN METODE}

\section{A. Bahan}

Bahan yang digunakan dalam kajian ini adalah data dan informasi tentang efisiensi pemanfaatan kayu merbau yang meliputi teknologi pengolahan, kebutuhan dan pasokan bahan baku, tingkat dan bentuk produk serta aspek pemasaran. Berkaitan dengan relokasi, bahan kajian berupa data potensi kayu merbau saat ini dan perkiraan produksi kayu di masa mendatang, keadaan industri pengolah kayu merbau di Papua, tata usaha kayu merbau, sarana-prasarana dan sumber daya manusia yang menjadi faktor pendukung dan penghambat upaya relokasi industri pengolahan kayu merbau ke Papua.

\section{B. Metode}

\section{Pendekatan masalah}

Untuk menjawab permasalahan ditempuh kegiatan lapangan dan studi pustaka untuk mencari data dan informasi pendukung. Kegiatan lapangan meliputi kunjungan ke beberapa instansi pemerintah pusat dan propinsi, perusahaan swasta, lembaga swadaya masyarakat (LSM) dan asosiasi. Faktor yang dikaji adalah potensi kayu merbau dan tingkat teknologi pengolahan kayu merbau di Papua. Sangat banyak aspek yang terkait, namun sesuai dengan dana dan waktu, kajian menekankan pada aspek-aspek keunggulan komparatif untuk mengembangkan strategi kompetensi inti yaitu bahan baku kayu merbau.

\section{Pengumpulan data}

Pengumpulan data dilakukan melalui wawancara, kuesioner dan pengamatan lapangan. Daftar instansi dan perusahaan yang menjadi sumber data dan informasi disajikan dalam Tabel 1 . 
Tabel 1. Instansi pemerintah dan perusahaan swasta sebagai sumber data dan informasi. Table 1. The list of Government, non-government organization and private companies as data and information sources.

\begin{tabular}{|c|c|c|}
\hline No & $\begin{array}{l}\text { Nama instansi \& perusahaan } \\
\text { (Offices and companies) }\end{array}$ & Lokasi (Location) \\
\hline 1 & $\begin{array}{l}\text { Direktorat Jenderal Bina Produksi Kehutanan } \\
\text { 1.1 Direktorat Bina Pengembangan Hutan Alam } \\
\text { 1.2 Direktorat Bina Rencana Pemanfaatan Hutan Produksi } \\
\text { 1.3 Direktorat Bina Pengolahan dan Pemasaran Hasil Hutan } \\
\text { 1.4 Direktorat Bina luran Kehutanan dan Peredaran Hasil Hutan }\end{array}$ & Jakarta \\
\hline 2 & Pelabuhan Karang Antu, Satpel Hutbun & Serang (Banten) \\
\hline 5 & $\begin{array}{l}\text { 5.1 Dinas Kehutanan Propinsi Papua } \\
\text { 5.2 Dinas Perindustrian dan Perdagangan Propinsi Papua } \\
\text { 5.3 Dinas Tenaga Kerja Propinsi Papua } \\
\text { 5.4 Badan Pusat Statistik Propinsi Papua } \\
\text { 5.5 UPTD Kehutanan Jayapura } \\
\text { 5.6 Pelabuhan Kayu Jayapura }\end{array}$ & Jayapura (Papua) \\
\hline 6 & PT Sijas Ekspress & Jayapura (Papua) \\
\hline 7 & Indonesia Sawmill and Woodworking Assoiation (ISWA) & Jakarta \\
\hline 8 & $\begin{array}{l}\text { 8.1 Departement For International Development (DFID) } \\
\text { 8.2 Conservation International }(\mathrm{CI}) \\
\text { 8.3 World Wild Foundatioan (WWF) }\end{array}$ & Jayapura (Papua) \\
\hline
\end{tabular}

\section{Analisa Data}

Hipotesis yang dikemukakan dalam kajian ini adalah efisiensi pemanfaatan kayu merbau masih dapat ditingkatkan dan relokasi industrinya kayu merbau dari Jawa Timur ke Papua beralasan dilakukan. Untuk membuktikan hipotesis, seluruh data yang diperoleh dikompilasi, ditabulasi dan dianalisis.

\section{HASILDAN PEMBAHASAN}

\section{A. Karakteristik, Potensi dan Produksi Kayu Merbau}

\section{Hutan produksi Papua}

Luas hutan produksi tetap di Papua seluas 10.585.210 ha, dan pemanfaatan kayu pada fungsi hutan produksi yang dapat dikonversi seluas \pm 9.000 .000 ha. Pemanfaatan hasil kayu berupa pohon layak tebang diameter $50 \mathrm{~cm}$ per hektar rata-rata 16 pohon. Sedangkan hasil cruising secara partial pada kawasan hutan fungsi produksi rata-rata volume kayu komersil kisaran 29,68 54,70 $\mathrm{M}^{3} / \mathrm{ha}$. Potensi jenis komersial tergolong rendah, namun sebaliknya keragaman jenis kayu relatif tinggi (Rajaar, 2002).

Berdasarkan Peta Paduserasi Propinsi Papua tahun 1999, tata guna hutan di Papua seperti tercantum dalam Tabel 2. 
KaiianEfisiensi Peranfaatan Kayu Merbau... . J amaludin Malik, Osy Radman, J amal Balfas dan AdmadSupriad

Tabel 2. Luas hutan Papua berdasarkan Peta Kawasan Hutan dan Perairan Provinsi Papua Table 2. Papua forest area based on Map of Forest and Terestrial Area

\begin{tabular}{|c|l|c|c|}
\hline \multirow{2}{*}{ No } & \multicolumn{1}{|c|}{$\begin{array}{c}\text { Fungsi hutan } \\
\text { (Forest function) }\end{array}$} & \multicolumn{2}{c|}{ Luas (Area) } \\
\cline { 3 - 4 } & \multicolumn{1}{|c|}{ Ha } & $\%$ \\
\hline 1 & Hutan Suaka Alam/Pelestarian Alam & 7.539 .300 & 17,86 \\
\hline 2 & Hutan Lindung & 10.619 .090 & 25.15 \\
\hline 3 & Hutan Produksi Terbatas & 2.054 .110 & 4.86 \\
\hline 4 & Hutan Produksi & 10.585 .210 & 25.07 \\
\hline 5 & Hutan Produksi Yang Dapat Dikonversi & 9.262 .130 & 21.94 \\
\hline 6 & Kawasan Perairan Jumlah (Total) & 1.678 .480 & 3,96 \\
\hline & & 42.224 .840 & 100 \\
\hline
\end{tabular}

Sumber (Source): Anonim (2001)

Data Badan Planologi Kehutanan (Anonim, 2002) menyebutkan total luas penutupan lahan terhadap kawasan hutan berdasarkan penafsiran citra satelit landsat ETM7 tahun 2000 seluas 40.849.000 Ha yang terdiri dari Kawasan Suaka Alam, Hutan Lindung, Hutan Produksi Tetap, Hutan Produksi Terbatas, Hutan Produksi Yang Dapat Dikonversi dan Areal Penggunaan Lain. Status hutan di Propinsi Papua sebagian besar merupakan hutan negara yang didalamnya termasuk hutan ulayat. Pemanfaatan hutan untuk pengembangan kegiatan ekonomi oleh investor akan dikenakan biaya kompensasi akibat pemanfaatan hutan yang akan diberikan kepada pemilik hak ulayat.

Berdasarkan Statistik Kehutanan yang diterbitkan oleh Dinas Kehutanan Propinsi Papua Tahun 2001 (Tabel 3), sejak tahun 1996 hingga 2000 terdapat sekitar 52 HPH/IUPHHK (Hak Pengusahaan Hutan/ljin Usaha Pemanfaatan Hasil Hutan Kayu), baik yang tergabung dalam group maupun non group, beroperasi di areal Hutan Produksi Terbatas (HPT), Hutan Produksi Tetap (HP) dan Hutan Produksi yang dapat dikonversi (HPK) dan telah mendapat Surat Keputusan Rencana Karya Tahunan (SK RKT) dengan target kumulatif luas produksi $830.500,56 \mathrm{Ha}$ dan target volume sebesar $17.291 .316,78 \mathrm{~m}^{3}$.

Tabel 3. Rekapitulasi produksi kayu bulat asal HPH di Papua Th 1996/1997 2000

Table 3. Summary of log production from forest concession company in Papua from 1996/97-2000

\begin{tabular}{|c|c|c|c|c|c|c|}
\hline \multirow[b]{2}{*}{ No } & \multirow[b]{2}{*}{$\begin{array}{c}\text { Tahun } \\
\text { (Years) }\end{array}$} & \multirow{2}{*}{\begin{tabular}{|c|} 
HPH yang \\
mendapat SK. RKT \\
(Concession company \\
that approved RKT)
\end{tabular}} & \multicolumn{2}{|c|}{ Rencana (Planned) } & \multicolumn{2}{|c|}{ Realisasi (Realization) } \\
\hline & & & $\begin{array}{c}\text { Luas } \\
\text { (Width), } \\
\mathrm{Ha}\end{array}$ & $\begin{array}{c}\text { Volume } \\
\left(\mathrm{M}^{3}\right)\end{array}$ & $\begin{array}{c}\text { Luas } \\
\text { (Width), } \\
\mathrm{Ha}\end{array}$ & $\begin{array}{c}\text { Volume } \\
\left(\mathrm{M}^{3}\right)\end{array}$ \\
\hline 1. & 1996/1997 & 51 & $195,872.00$ & $3,682,995.00$ & $113,837.46$ & $2,143,729.33$ \\
\hline 2. & $1997 / 1998$ & 52 & $171,137.00$ & $3,519,536.00$ & $113,525.97$ & $2,272,269.08$ \\
\hline 3. & $1998 / 1999$ & 52 & $144,572.84$ & $3,015,958.56$ & $74,422.76$ & $1,459,210.19$ \\
\hline 4. & $1999 / 2000$ & 52 & $159,459.36$ & $3,412,641.22$ & $74,598.43$ & $1,487,921.89$ \\
\hline 5. & $2000 / 2001$ & 52 & $159,459.36$ & $3,660,186,00$ & $74,598.43$ & $1,096,105.45$ \\
\hline & Jumlah & 259 & $830,500.56$ & $17,291,316.78$ & $448,983.06$ & $8,459,235.92$ \\
\hline
\end{tabular}

Sumber (Source) : Anonim (2001) 
Jumlah HPH di Papua terus berkurang. Pada tahun 2003 jumlah HPH yang mendapatkan pengesahan RKT sebanyak 35 perusahaan (Dinas Kehutanan Propinsi Papua, 2003) yang tidak semuanya aktif. Menurut Latumahina dari DFID Papua (2003), jumlah HPH yang benar-benar aktif beroperasi di Papua saat ini tinggal 12 unit.

Selain HPH/IUPHHK, badan usaha yang mengelola dan memanfaatkan hasil hutan di Papua adalah IPK/IPKL (Ijin Pemanfaatan Kayu/ljin Pemanfaatan Kayu Limbah) dan KOPERMAS/IPKMA (Koperasi Peran Serta Masyarakat/ljin Pemanfaatan Kayu oleh Masyarakat Adat). Data dari Dinas Kehutanan Papua menunjukkan bahwa dalam periode April 2001 Agustus 2003 terdapat 57 IPK/IPKL, baik perpanjangan maupun baru, yang mendapatkan ijin. Sedangkan untuk periode September 2002 Juni 2003 terdapat 102 IPKMA/Kopermas yang mendapatkan ijin baru yang berakhir bulan September 2002. Menurut Dinas Koperasi Papua (Worembae, 2003), jumlah keseluruhan IPKMA/KOPERMAS yang telah berdiri di Papua sebanyak 441 unit dan telah terbentuk 1 unit Pusat Koperasi (PUSKOPERMAS). IPK/IPKL mengelola areal hutan seluas 1000 6000 ha sedangkan IPKMA/KOPERMAS mengelola 1000 ha dalam setiap ijinnya.

Jenis-jenis kayu yang dapat dimanfaatkan dikelompokkan ke dalam Kelompok Meranti, Kelompok Kayu Indah dan Kelompok Kayu Campuran. Kelompok kayu meranti terdiri dari: Matoa (Pometia spp.), Merbau (Intsia spp.), Mersawa (Anisoptera spp.), Kenari (Canarium spp.), Nyatoh (Palaquium spp.), Resak (Vatica spp.), Pulai (Alstonia spp.), Damar (Agathis spp.), Araucaria (Araucaria spp.), Kapur (Dryobalanops spp.), Batu (Shorea spp.), Mangga hutan (Mangifera spp.), Celthis (Celthis spp.), dan Kayu Cina (Podocarpus spp.). Kelompok Kayu Indah terdiri dari jenis: Dahu (Dracontomelon spp.), Linggua (Pterocarpus spp.), dan Kuku. Kelompok Kayu Campuran terdiri dari: Ketapang, Binuang, Bintangur, Terentang, Bipa, Kayu Bugis, Cempaka, Pala hutan. Potensi kayu ini sudah dimanfaatkan/diusahakan dalam bentuk Hak Pengusahaan Hutan (HPH) dan industri pengolahan kayu (Rajaar, 2002).

\section{Karakteristik kayu merbau}

Merbau (Intsia spp.) dari famili Caesalpiniaceae adalah salah satu kayu bernilai tinggi yang banyak terdapat terutama di Propinsi Papua, selain Aceh dan Maluku. Kayu ini memiliki berat jenis tinggi, BJ maksimum 1,08, minimum 0,52 dan rata-rata 0,84. Kekerasan rata-rata kayu merbau sangat tinggi, dibanding jenis kayu komersial di dunia. Menurut Suwarsono (1963), kekerasan kayu merbau (Intsia bijuga O.K.) dari Indonesia adalah $842 \mathrm{~kg} / \mathrm{cm}^{2}$. Nilai ini lebih tinggi dari kempas (610 $\mathrm{kg} / \mathrm{cm}^{2}$, keruing $\left(427 \mathrm{~kg} / \mathrm{cm}^{2}\right)$ dan Nyatoh $\left(302 \mathrm{~kg} / \mathrm{cm}^{2}\right)$. Faktor-faktor inilah yang dijadikan alasan sulitnya mengembangkan industri (menggergaji) kayu merbau di Papua. Kayu merbau termasuk kelas kuat I - II dan kelas awet I - II. Kayu merbau sangat baik untuk flooring dan panel dinding karena memberi kesan indah, teduh dan alami (Soerianegara dan Lemmens, 2002)..

\section{Potensi kayu merbau}

Bahan baku merupakan salah satu aspek terpenting dalam industri. Potensi kayu merbau sebagai bahan baku industri perlu diketahui secara pasti untuk menjamin kelestarian industri. Potensi kayu merbau di Indonesia berdasarkan literatur banyak terdapat di Aceh, Maluku dan Papua. Namun demikian, di Papua-lah jenis kayu ini berpotensi paling besar karena jenis tersebut merupakan salah satu jenis dominan yang tumbuh di hutan Papua yang luas (Soerianegara dan Lemmens, 2002; Martawijya et al., 1989).

Beberapa kalangan menilai bahwa potensi kayu merbau untuk produksi di Papua sebenarnya rendah. Latumahina dari DFID Papua (2003) menyebutkan bahwa potensi kayu merbau 
layak tebang dari hutan produksi Papua adalah 1011 pohon/ha areal penebangan. Demikian pula aktivis Conservation International (Cl) dan World Wild Foundation (WWF) menyatakan bahwa potensi kayu merbau di Papua rendah. Mereka menganggap adanya mis-interpretasi terhadap nilai kayu merbau (valuable timber) yang dapat dimanfaatkan dari hutan Papua. Dengan adanya penebangan besar-besaran kayu merbau sampai saat ini, sementara penanaman kembali kayu merbau belum terbukti keberhasilannya, dikhawatirkan kayu merbau akan punah. Sehingga diusulkan agar kayu merbau dimasukkan dalam Appendix II CITES (Pangkali, 2003; Fretes, 2003).

Sementara itu, pihak Pemerintah Daerah Propinsi Papua c.q Dinas Kehutanan Propinsi Papua berkeyakinan bahwa potensi kayu merbau di Papua masih cukup besar dan diperkirakan akan mampu memasok kebutuhan bahan baku industri untuk jangka waktu lebih dari 5 tahun. Hal ini dibuktikan dengan besarnya volume produksi kayu merbau selama 9 tahun terakhir (Tabel 7), meskipun cenderung menurun.

Berdasarkan Laporan Hasil Cruising (LHC) dari $10 \mathrm{HPH}$ yang tersebar di tujuh kabupaten di Papua, diketahui bahwa potensi kayu merbau yang terdiri dari pohon inti ( $?=20-49 \mathrm{~cm})$ dan kayu perdagangan berdiameter $50 \mathrm{~cm}$ up bervariasi per hektar areal hutan produksi. Untuk pohon inti jumlah pohon berkisar antara 22 - 59 pohon/ha dengan volume $16-37 \mathrm{~m}^{3} / \mathrm{ha}$, sedangkan untuk kayu perdagangan berkisar antara 5 - 15 pohon/ha dengan volume $11-55 \mathrm{~m}^{3} / \mathrm{ha}$. Dengan demikian potensi pohon inti untuk setiap HPH rata-rata sebesar 36,81 pohon/ha dengan volume $26,16 \mathrm{~m}^{3} / \mathrm{ha}$ dan potensi pohon produksi sebesar 9,11 pohon/ha dengan volume $33,11 \mathrm{~m}^{3} / \mathrm{ha}$. Selengkapnya data potensi dan sebarannya berdasarkan HPH dan Kabupaten di Papua dicantumkan dalam Tabel 4.

Tabel 4. Potensi dan sebaran kayu merbau di Papua menurut Kabupaten Table 4. Potential and distribution of merbau trees in Papua area, by district

\begin{tabular}{|c|l|c|c|c|c|c|}
\hline & & & \multicolumn{4}{|c|}{ Potensi tegakan (Stand potential) } \\
\cline { 4 - 7 } No & Kabupaten (Districts) & $\begin{array}{c}\text { Luas hutan *) } \\
\text { (Forest area), } \\
\text { Ha }\end{array}$ & & \multicolumn{2}{|c|}{$\phi 20-49 \mathrm{~cm}$} & \multicolumn{2}{|c|}{$\phi 50$ up } \\
\cline { 4 - 7 } & & 1.674 .869 & 30.3 & 25.8 & 9.3 & 33.9 \\
\hline 1 & Jayapura & 1.315 .190 & 39.2 & 36.8 & 9.4 & 23.7 \\
\hline 2 & Serui/Yapen Waropen & 1.352 .550 & 41.2 & 18.5 & 10.2 & 37.9 \\
\hline 3 & Sorong & 1.524 .700 & 19.2 & 27.9 & 12.9 & 46.4 \\
\hline 4 & Manokwari & 834.500 & 29.4 & 21.7 & 8.4 & 31.5 \\
\hline 5 & Kaimana/Mimika & 1.475 .310 & 42.9 & 29.3 & 10.2 & 27.4 \\
\hline 6 & Fakfak & 390.510 & 32.4 & 29.5 & 9.2 & 32.2 \\
\hline 7 & Nabire & 8.567 .679 & 234.6 & 189.5 & 69.6 & 233 \\
\hline & & 33.51 & 27.07 & 9.94 & 33.29 \\
\hline
\end{tabular}

Keterangan (Remarks) : *) Berdasarkan jumlah luas HPH (Based on concession area) $\mathrm{N}=$ jumlah pohon (Number of tree); phn/ha (Tree/ha)

Sumber(Sources) : Dinas Kehutanan Papua/Papua Province Forest Service (Anonim, 2003a) dan/and Rachman, E. (2003), diolah/summarized 
Optimisme Pemerintah Propinsi Papua cukup beralasan karena berdasarkan potensi di atas, tiap tahun dari Papua dapat diproduksi kayu merbau dengan perhitungan sebagai berikut : Daur merbau $=60$ tahun, faktor eksploitasi $=0,7$, angka bentuk $=0,8$, luas tebangan tahunan $=$ $8.567 .679 / 60=142.795 \mathrm{Ha} /$ th. Jadi potensi kayu yang dapat diproduksi setiap tahun $(A A C)=$ $142.795 \times 33,29 \times 0,7 \times 0,8=2,662$ juta $\mathrm{m}^{3} /$ th. Jika potensi tersebut efektif dapat memenuhi kebutuhan industri, maka perkiraan produksi kayu merbau dapat memenuhi kebutuhan industri untuk lima tahun ke depan, dapat diterima.

Adanya dua pandangan yang berbeda tentang potensi kayu merbau menunjukkan perlunya perhitungan kembali (rekalkulasi) potensi dengan memadukan kedua anggapan tersebut. Pihak Dinas Kehutanan Papua, merasakan pentingnya rekalkulasi tersebut dilakukan terlebih dahulu, kemudian secara simultan mendisain ulang areal HPH, sebelum restrukturisasi industri dilakukan. Dengan demikian akan ada kepastian tentang keberlangsungan pasokan bahan baku kayu merbau ke industri.

\section{Produksi kayu merbau}

Meskipun beberapa kalangan menganggap potensi kayu merbau di Papua rendah, akan tetapi karena hutan produksi masih luas, Dinas Kehutanan memberikan jatah tebangan kepada HPH, IPK dan IPKMA untuk setiap kabupaten penghasil kayu merbau. Sebagai gambaran, jatah produksi HPH sesuai RKT dan ijin pemanfaatan yang disahkan untuk setiap kabupaten di Papua seperti tercantum dalam Tabel 5. Sedangkan jatah tebangan yang diberikan kepada kedua jenis badan usaha tersebut disajikan pada Tabel 6 . Berdasarkan potensi kayu merbau yang ada, Pemerintah Provinsi Papua optimis dapat memasok kebutuhan industri dalam jangka waktu 2030 tahun dengan asumsi kapasitas total industri pengolah kayu merbau (Sawmill) sama seperti sekarang, berdasarkan data dari BSPHH (Anonim, 2003b), sebesar $650.565 \mathrm{~m}^{3} /$ tahun .

Tabel 5. Jatah tebangan kayu merbau pada HPH menurut kabupaten di Papua Th. 2003 Table 5. Allowable cut of merbau wood for concessions companies by district in Papua in 2003

\begin{tabular}{|c|l|c|c|}
\hline No & \multicolumn{1}{|c|}{ Kabupaten (Districts) } & $\begin{array}{c}\text { Luas Hutan Produksi } \\
\text { (Production forest area), Ha }\end{array}$ & $\begin{array}{c}\text { Jatah tebangan } \\
\text { (Allowable cut), }{ }^{3}\end{array}$ \\
\hline 1 & Jayapura & 1.765 .919 & $256.423,48$ \\
\hline 2 & Merauke & 3.406 .400 & $8.437,34$ \\
\hline 3 & Yapen Waropen & 1.400 .800 & $38.938,99$ \\
\hline 4 & Sorong & 1.352 .550 & $86.631,90$ \\
\hline 5 & Manokwari & 1.692 .940 & $145.727,52$ \\
\hline 6 & Mimika & 834.500 & $18.631,90$ \\
\hline 7 & Fakfak Jumlah & 1.475 .310 & $157.036,37$ \\
\hline \multicolumn{2}{|r|}{} & 11.928 .410 & $711.827,50$ \\
\hline
\end{tabular}

Sumber (Source) : Dinas Kehutanan Provinsi Papua/Papua Province Forest Service (Anonim, 2003a), diolah/summarized 
Tabel 6. Jatah tebangan kayu merbau dari IPK dan IPKMA tahun 2003

Table 6. Allowable cut of merbau wood for IPK and IPKMA in 2003

\begin{tabular}{|r|c|c|}
\hline $\begin{array}{c}\text { Badan usaha } \\
\text { (Bussiness units) }\end{array}$ & $\begin{array}{c}\text { Luas hutan produksi } \\
\text { (Width of production forest area), Ha }\end{array}$ & $\begin{array}{c}\text { Jatah tebangan } \\
\text { (Allowable cut), } \mathrm{m}^{3}\end{array}$ \\
\hline IPK/IPKL & 91.868 & $256.423,48$ \\
\hline IPKMA & 96.250 & $8.437,34$ \\
\hline Jumlah & 188.118 & $38.938,99$ \\
\hline
\end{tabular}

Sumber (Source) : Dinas Kehutanan Provinsi Papua/Papua Province Forest Service (Anonim, 2003a), diolah/summarized

Terdapat kesulitan menghitung volume khusus kayu merbau sebelum tahun 2002 karena dalam rekapitulasi dokumen kayu merbau dimasukkan dalam kelompok meranti. Namun demikian berdasarkan pengalaman produksi kayu oleh HPH di Papua, volume merbau rata-rata sebesar $30 \%$ dari total produksi kayu bulat. Sehingga dapat diperkirakan volume kayu merbau dapat dilihat pada Tabel 7. Produksi kayu merbau dari Papua berdasarkan tabel tersebut cenderung terus menurun dalam sepuluh tahun terakhir.

Tabel 7. Produksi kayu bulat Propinsi Papua tahun 1994/1995 2003

Table 7. Logs production in Papua Province during 1994/1995 2003

\begin{tabular}{|c|c|c|c|}
\hline No & Tahun (Year) & $\begin{array}{c}\text { Produksi Kayu Bulat } \\
\text { (Production of Logs), } \mathrm{m}^{3}\end{array}$ & $\begin{array}{c}\text { Produksi Kayu Bulat Merbau } \\
\text { (Production of Merbau Logs), } \mathrm{m}^{3}\end{array}$ \\
\hline 1 & $1994 / 1995$ & $2.349 .609,27$ & $704.882,79$ \\
\hline 2 & $1995 / 1996$ & $1.640 .662,70$ & $492.198,81$ \\
\hline 3 & $1996 / 1997$ & $1.899 .614,10$ & $569.884,23$ \\
\hline 4 & $1997 / 1998$ & $2.180 .655,82$ & $654.196,74$ \\
\hline 5 & $1998 / 1999$ & $1.506 .755,71$ & $452.026,71$ \\
\hline 6 & $1999 / 2000$ & $762.325,33$ & $228.697,60$ \\
\hline 7 & 2001 & $828.041,30$ & $248.412,39$ \\
\hline 8 & 2002 & $484.292,57$ & $251.816,41$ \\
\hline 9 & 2003 & $170.722,23^{*}$ & $65.588,93^{*}$ \\
\hline
\end{tabular}

Keterangan (Remarks):

*) Sampai bulan Agustus 2003 dan masih banyak perusahaan yang belum melaporkan produksi kayunya terutama dari IPK dan IPKMA (Until August 2003 and some concessions have not given reports of their logs production, particularly from IPK and IPKMA).

Sumber (Source) : Dinas Kehutanan Propinsi Papua/Papua Province Forest Service (Anonim, 2003c) 
Menurut Dinas Kehutanan Papua (2003), kapasitas terpasang industri penggergajian (sawmill) di Papua mencapai lebih dari $600.000 \mathrm{~m}^{3} /$ th, sementara itu produksi kayu merbau $200-250$ ribu $\mathrm{m}^{3} /$ th. Produksi kayu merbau sebenarnya dapat memenuhi kapasitas sebesar $30-40 \%$ seandainya seluruh kayu merbau diolah di Papua. Tetapi jika tidak ada penambahan produksi, maka industri pengolah kayu merbau di Papua akan kekurangan bahan baku karena sebagian kayu bulat merbau diperlukan untuk industri di Jawa. Kondisi demikian tidak sinkron dengan adanya keinginan untuk mengekspor kayu bulat merbau. Hal tersebut juga menjadi alasan yang tepat bagi Pemerintah Pusat untuk melarang kegiatan ekspor kayu bulat.

\section{B. Peredaran Kayu Bulat Merbau}

\section{Peredaran kayu}

Produksi tersebut selain digunakan untuk bahan baku industri pengolahan kayu di Papua sendiri, juga sebagian kayu bulat didistribusikan ke luar Papua, baik ke luar negeri/ekspor (sebelum ekspor kayu bulat dilarang) maupun penjualan antar pulau. Selain kayu bulat, dari Papua juga didistribusikan kayu gergajian terutama ke Jawa yang akan diolah menjadi berbagai macam produk akhir. Sebagai ilustrasi, sampai dengan bulan Juli tahun 2003 dari Papua didistribusikan kayu sebanyak $112.767,29 \mathrm{~m}^{3}$ yang terdiri dari $13.211,29 \mathrm{~m}^{3}$ kayu gergajian dan $99.322,97 \mathrm{~m}^{3}$ kayu bulat (BSPHH Jayapura, 2003). Volume kayu bulat merbau yang diolah di Papua disajikan dalam Tabel 8.

Tabel 8. Kayu bulat merbau yang diolah di Papua

Table 8. Merbau logs processed in Papua

\begin{tabular}{|c|c|}
\hline Tahun (Year) & Volume (Volum), $\mathrm{m}^{3}$ \\
\hline 2001 & $242.155,70$ \\
\hline 2002 & $110.335,89$ \\
\hline 2003 & $\left.22018,82^{*}\right)$ \\
\hline
\end{tabular}

Keterangan (Remark) : *) Data sampai bulan Juli 2003 (Data available until July 2003)

Sumber (Source) : Dinas Kehutanan Propinsi Papua/Papua Province Forest Service (2003) dan/and BSPHH Jayapura (Anonim, 2003b)

\section{Hargakayu}

Harga kayu merbau di Jayapura berkisar antara Rp 900.000 Rp 1.100.000,- per m ${ }^{3}$ tergantung pada mutu kayu bulat. Penentuan mutu kayu bulat lebih didasarkan pada dimensinya terutama ukuran diameter, karena selama ini jarang ditemui cacat log baik cacat fisis maupun biologis. Secara rinci kisaran harga tersebut tercantum dalam Tabel 9. 
Tabel 9. Harga kayu bulat merbau tahun 2003 di Jayapura

Table 9. Price of merbau wood logs in Jayapura in 2003

\begin{tabular}{|c|c|}
\hline $\begin{array}{c}\text { Kelas mutu log } \\
\text { (Log quality) }\end{array}$ & $\begin{array}{c}\text { Harga log (Price of logs), } \\
\text { Rp per m }\end{array}$ \\
\hline $\mathrm{I}$ & 1.100 .000 \\
\hline $\mathrm{I}$ & 1.100 .000 \\
\hline $\mathrm{II}$ & 900.000 \\
\hline
\end{tabular}

Sumber (Source) : Unit Pelaksana Teknis Daerah (UPTD) Kehutanan Jayapura/Technical Execution Unit of Jayapura District (Anonim, 2003d)

Harga kayu bulat merbau sebagaimana Tabel 9 adalah harga log termasuk gubal, sesuai SK Menhut No. 179/Kpts-IV/Edar/2000 tanggal 7 September 2000. Sebelumnya harga kayu merbau ditetapkan tanpa gubal sesuai SK Dirjen Pengusahaan Hutan No. 74/Kpts-V/TPHH/1993.

\section{Industri Pengolahan Kayu Merbau di Papua}

\section{Kapasitas industri dan permasalahannya}

Di Papua terdapat 9 industri besar (kapsitas $>6.000 \mathrm{~m}^{3} /$ th) yang mengolah dolok merbau menjadi kayu gergajian, S2S dan S4S. Bahkan sudah ada industri besar yang mengolah kayu merbau menjadi produk akhir (finished product). Selain itu, terdapat 66 industri kecil (kapasitas < $6000 \mathrm{~m}^{3} / \mathrm{th}$ ) yang mengolah merbau menjadi kayu gergajian. Selain perusahaan yang tercatat dalam survey, kemungkinan masih terdapat industri kecil yang mengolah merbau.

Permasalahan utama industri kayu merbau di Papua adalah tidak optimalnya kapasitas yang ada. Hampir semua industri kekurangan bahan baku, sehingga program prioritas Pemerintah Propinsi Papua adalah optimalisasi kapasitas industri kayu, terutama 9 industri besar yang banyak menyerap banyak tenaga kerja.

Tidak optimalnya kapasitas industri kayu di Papua dapat dilihat dari besarnya kapasitas industri dengan realisasi produksi kayu merbau. Sebagaimana telah diketahui bahwa kapasitas industri kayu di Papua lebih dari $600.000 \mathrm{~m}^{3} /$ th, sedangkan produksi kayu merbau $200250 \mathrm{~m}^{3} /$ th dan tidak seluruhnya kayu bulat merbau tersebut di olah di Papua. Masalah kinerja industri kayu yang dibawah kapasitas ini, menjadikan argumentasi perlunya ekspor kayu bulat merbau, tidak dapat diterima.

\section{Efisiensi dan kendala teknis pengolahan}

Pengolahan kayu merbau di Papua oleh sebagian IPKMA di sekitar hutan masih dilakukan secara sederhana yaitu hanya menggunakan gergaji rantai (chain saw) sehingga rendemen penggergajian rendah, kayu gergajian yang dihasilkan masih kasar (balok kaleng) serta waktu penggergajian elative lama. Balok kaleng inilah yang menjadi bahan baku industri penggergajian, oleh industri diolah menjadi S2S atau S4S, kemudian diirim ke industri di luar Papua.

Harga jual balok kaleng jauh lebih rendah $\left(R p 1-1,1 \mathrm{juta} / \mathrm{m}^{3}\right)$ atau kurang lebih sama dengan harga kayu bulat merbau kelas mutu III di Jawa. Pengolahan kayu merbau menjadi balok kaleng 
memberikan nilai tambah yang rendah. Nilai tambah yang terbatas inilah yang dinikmati oleh sebagian besar masyarakat Papua yang terlibat dalam pengusahaan kayu merbau melalui IPKMA/Kopermas. Nilai tambah yang dapat dinikmati masyarakat masih sangat memungkinkan untuk ditingkatkan. Terbukti dengan mengolah kayu merbau menjadi kayu gergajian halus, harganya jauh lebih tinggi yaitu $R p 2,5-R p ~ 2,8 ~ j u t a / m^{3}$. Jika kemampuan industri pengolah kayu merbau di Papua ditingkatkan lagi sehingga mampu menghasilkan produk sekunder yang langsung dapat diekspor, maka nilai tambah yang dapat diperoleh akan lebih besar lagi.

\section{Sarana-Prasarana}

Yang dimaksudkan dengan sarana dan prasaran di sini meliputi sarana umum dan sarana khusus di industri pengolahan kayu merbau. Sarana umum sebagai penunjang operasionalisasi industri yang diperlukan berupa infrastruktur yang terdapat di daerah dimana industri berada seperti jalan, listrik, pelabuhan, alat komunikasi, dll. Sedangkan sarana khusus merupakan sarana operasional industri terutama mesin dan peralatan standar yang dibutuhkan dalam proses pengolahan kayu merbau.

Sarana-prasarana untuk menunjang industri pengolahan kayu merbau di Papua sebenarnya sudah cukup memadai (Tabel 10). Jika industri kayu merbau Papua telah mampu memproduksi produk akhir, maka sarana yang perlu dibangun atau dikembangkan adalah pelabuhan eksporimpor.

Tabel 10. Sarana-prasarana penunjang industri

Table 10. Infrastructure supporting wood industries

\begin{tabular}{|l|l|l|}
\hline \multicolumn{1}{|c|}{$\begin{array}{c}\text { Sarana, prasarana } \\
\text { (Infrastructures) }\end{array}$} & \multicolumn{1}{|c|}{$\begin{array}{c}\text { Uraian } \\
\text { (Description) }\end{array}$} & \multicolumn{1}{|c|}{$\begin{array}{c}\text { Keadaan di Jayapura } \\
\text { (Jayapura condition) }\end{array}$} \\
\hline Jalan (Road) & $\begin{array}{l}\text { Aksesibilitas (Accessibility) } \\
\text { Kelas jalan (Road class) } \\
\text { Jarak industri - Pelabuhan Kayu } \\
\text { (Distance between mill - wood harbor) }\end{array}$ & $\begin{array}{l}\text { Mudah (Easy) } \\
\text { C } \\
20-100 \mathrm{~km}\end{array}$ \\
\hline Pelabuhan (Harbor) & $\begin{array}{l}\text { Eskpor/Impor (Export/Import) } \\
\text { Domestik (Domestic) }\end{array}$ & $\begin{array}{l}\text { Tidak ada (None) } \\
\text { Ada (Established) }\end{array}$ \\
\hline Listrik (Electric) & $\begin{array}{l}\text { PLN } \\
\text { GENSET }\end{array}$ & Memadai (Sufficient) \\
\hline $\begin{array}{l}\text { Fasilitas air } \\
\text { (Water facility) }\end{array}$ & Sumur Bor (Artesian well) & Memadai (Sufficient) \\
\hline $\begin{array}{l}\text { Fasilitas telpon } \\
\text { (Phone facility) }\end{array}$ & PDAM & Memadai (Sufficient) \\
\hline
\end{tabular}




\section{E. Sumber Daya Manusia}

Faktor sumber daya manusia (SDM) adalah satu di antara tiga faktor utama yang menentukan keberhasilan industri pengolahan kayu. Kualifikasi SDM untuk industri pengolahan kayu merbau secara umum tidak berbeda dengan industri kayu lainnya. Untuk satu unit industri pengolah kayu merbau yang terdiri dari bagian pokok sawmill dan woodworking memerlukan tenaga kerja dengan kualifikasi tertentu. Adapun jumlah dan struktur SDM disesuaikan dengan kapasitas industri.

Pengolahan kayu oleh IPKMA di Papua masih terbatas sampai kayu gergajian kasar dan hampir semua industri penggergajian (IPKH) mengolah kayu merbau hanya sampai produk S2S/S4S. Dalam rangka meningkatkan efisiensi dan diversifikasi pemanfaatan kayu merbau diperlukan peningkatan kemampuan SDM sehingga mampu mengolah kayu merbau menjadi finished product seperti yang telah dilakukan oleh industri di Jawa.

Sesuai target Dinas Kehutanan Propinsi Papua untuk optimalisasi industri besar, kebutuhan tenaga kunci pengolahan merbau dapat diperkirakan. Dengan asumsi jumlah tenaga kunci sebanyak 40 orang tiap unit industri, maka untuk industri besar pengolah kayu merbau saat ini di Papua memerlukan tenaga kunci 40 orang $\times 9$ industri $=360$ orang. Tenaga inilah yang perlu ditingkatkan kemampuannya sehingga SDM bukan penghambat pengembangan industri pengolah kayu merbau di Papua seperti yang sering dikeluhkan saat ini.

\section{F. Kebijakan yang Terkait dengan Pengelolaan Kayu Merbau}

Pelarangan ekspor kayu bulat (SK. Menperindag no. 575/MPP/KEP/VIII/2002 6 Agustus 2002) jika dilaksanakan dengan benar, dapat membawa dampak positif bagi berbagai pihak, seperti bagi industri pengolahan kayu dalam negeri, masyarakat dan pemerintah/negara. Larangan ekspor kayu bulat, dapat memberikan kesempatan kepada industri pengolahan kayu dalam negeri dalam memenuhi kebutuhan bahan bakunya. Meskipun masih terjadi gap antara tingkat kebutuhan bahan baku oleh industri dalam negeri dengan jumlah pasokan kayunya, akan tetapi dengan pelarangan ekspor kayu bulat, paling tidak persaingan secara langsung dengan industri dari luar Indonesia dalam pemenuhan kayu bulat tidak terjadi. Bagi masyarakat, pelarangan ekspor kayu bulat juga memberikan berbagai keuntungan, antara lain terbukanya kesempatan untuk bekerja pada industri pengolah kayu di dalam negeri, sehingga masyarakat dapat memperoleh penghasilan dalam memenuhi kebutuhan hidupnya. Pelarangan ekspor juga menguntungkan bagi pemerintah/negara, karena dapat meningkatkan devisa negara, dapat menekan angka pengangguran dan dapat menekan timbulnya berbagai kerawanan sosial. Selain itu, pelarangan ekspor kayu bulat juga dapat menekan laju ekspoitasi hasil hutan (kayu) secara berlebihan.

Sebelumnya Gubernur Papua melalui SK. No. 72 tahun 2002 tanggal 18 Juni 2002 telah membolehkan ekspor kayu bulat jenis merbau di Propinsi Papua. Pertimbangannya adalah penghentian ekspor kayu bulat telah berdampak kurang menguntungkan terhadap stabilitas sosial ekonomi masyarakat. Ekspor kayu bulat dilakukan dalam rangka meningkatkan penerimaan devisa, pendapatan daerah dan meningkatkan daya saing hasil hutan. Tetapi SK Gubernur tersebut belum sempat efektif dipergunakan.

Pertimbangan bahwa penghentian ekspor menjadi penyebab ketidak-stabilan kondisi sosial ekonomi msyarakat masih perlu diperjelas lagi. Apakah ada hubungan yang signifikan antara penghentian ekspor kayu bulat dengan tidak stabilnya kondisi sosial ekonomi masyarakat? Karena banyak faktor lain yang berpengaruh kepada stabilitas sosial dan ekonomi, antara lain kondisi makro ekonomi, stabilitas politik, jaminan kepastian hukum, berbagai kebijakan pemerintah, kondisi internasional dan lain sebagainya. 
Kegiatan ekspor kayu bulat merupakan cara yang relatif cepat dalam mendatangkan devisa bagi negara dan pendapatan daerah. Akan tetapi, dengan diekspornya kayu bulat maka masyarakat akan kehilangan kesempatan memperoleh pekerjaan terutama pada karena industri pengolah kayu di dalam negeri akan makin sulit berkembang akibat kekurangan bahan baku. Bahkan, kemungkinan besar akan banyak masyarakat yang kehilangan pekerjaan. Dampak ini akan memicu ketidak stabilan sosial dan ekonomi di masayarakat.

Pertimbangan bahwa ekspor kayu bulat akan meningkatkan daya saing produk adalah kurang tepat, karena ekspor kayu bulat dapat menurunkan daya saing industri dalam negeri. Selain industri dalam negeri makin sulit memperoleh bahan baku, juga di pasar nasional dan internasional akan muncul pesaing-pesaing industri hasil hutan terutama dari negara-negara pengimpor kayu bulat yang lebih unggul dan efisien dalam teknologi pengolahan kayu.

Meskipun ekspor kayu bulat telah dilarang, akan tetapi disinyalir masih sering terjadi penjualan kayu bulat ke luar negeri secara tidak sah (illegal).. Hal ini kemungkinan terjadi karena penjualan kayu bulat ke luar negeri lebih menarik dibandingkan jika dijual di dalam negeri. Ekspor ilegal juga akan lebih menguntungkan bagi pelaku karena terhindar dari biaya-biaya yang harus dikeluarkan bila ekspor dilakukan secara legal. Kemungkinan penyebab lainnya masih lemahnya tingkat pengawasan di lapangan terhadap lalu lintas perdagangan kayu. Dalam upaya menanggulangi ekspor kayu illegal, pemerintah telah menerbitkan Surat Keputusan Bersama 3 Menteri yaitu Menteri Perhubungan (No. KM 3 thn 2003), Menperindag (No. 33/MPP/Kep/1/2003) dan Menteri Kehutanan (No. 22/Kpts-II/2003) tentang Pengawasan pengangkutan kayu melalui pelabuhan. Dimana dalam pengangkutan kayu, Pemilik kayu wajib menunjukkan Surat Keterangan Sahnya Hasil Hutan (SKSHH) dan Daftar Hasil Hutan (DHH) kepada petugas-petugas yang berwenang memeriksa di pelabuhan. Akan tetapi, penyelundupan kayu masih sering terjadi lapangan. Menurut seorang pelaku usaha kayu merbau, diperkirakan lebih dari $30 \%$ kayu merbau diekspor ke luar negeri secara illegal. Untuk menekan laju ekspor illegal, dibutuhkan berbagai upaya secara terpadu dan berkesinambungan, antara lain dalam hal aspek insentif (misalnya harga jual kayu di dalam negeri yang menarik), aspek pengawasan, aspek kepastian hukum dan aspek politis.

Kebijakan lainnya adalah SK Menhut No. 179/Kpts-IV/Edar/2000 tanggal 7 September 2000 yang mencabut SK Dirjen Pengusahaan Hutan No. 74/Kpts-V/TPHH/1993 tentang penetapan volume merbau. Dengan dicabutnya SK Dirjen tersebut, perhitungan volume kayu merbau saat ini adalah termasuk gubalnya. Sebagian kalangan keberatan dengan kebijakan tersebut dengan alasan bahwa bagian gubal kayu merbau bernilai sangat rendah, sementara porsinya pada log sebesar 15 - 20\%. Pihak yang keberatan menyatakan seolah-olah perusahaan membayar bagian yang terbuang dari kayu merbau. Akan tetapi hasil pengamatan di lapangan menunjukkan bahwa bagian gubal kayu merbau masih dapat dibuat berbagai produk olahan untuk konsumsi dalam negeri.

Kebijakan pemerintah lainnya adalah yang berkenaan dengan kegiatan ekspor hasil hutan. Berdasarkan Surat Keputusan Badan Revitalisasi Industri Kehutanan nomor 005/BRIK/Umum/ III/2003 7 Februari 2003, kegiatan ekspor produk industri kehutanan hanya dapat dilaksanakan oleh Perusahaan Industri Kehutanan yang telah diakui sebagai Eksportir Terdaftar Produk Industri Kehutanan (ETPIK). ETPIK harus mengajukan Rencana Ekspor ke Badan Revitalisasi lindustri Kehutanan (BRIK), dengan dilengkapi Laporan Mutasi Kayu yang berisi persediaan kayu, SKSHH. Setelah lengkap BRIK akan menerbitkan nomor pengesahan (endorsment), kemudian baru ETPIK dapat melaksanakan kegiatan ekspor. Kebijakan ini cukup menyulitkan bagi industri/ekportir yang berlokasi jauh dari Jakarta. Sebagai contoh untuk industri/eksportir yang berlokasi di Papua, akan memerlukan waktu dan biaya yang tidak sedikit dalam melakukan kegiatan ekspor produknya. 
Disarankan bahwa kebijakan ini dapat diperbaharui terutama untuk memberikan kemudahan bagi industri/eksportir yang berlokasi jauh dari Jakarta, misalnya dengan mendelegasikan/mendirikan cabang BRIK di kota Indonesia bagian Timur.

Implementasi kebijakan di lapangan yang mengakibatkan tingginya biaya produksi cepat atau lambat akan mematikan industri kayu dalam negeri karena kalah bersaing dengan pelaku usaha luar negeri. Sehingga memerlukan dukungan pemerintah dalam penegakan hukum (law enforcement). Untuk menjamin kelestarian industri pengolahan kayu merbau sebaiknya potensi merbau diketahui secara pasti. Selain itu pemerintah perlu membatasi industri pengolah merbau disesuaikan dengan potensi pasokan kayunya.

\section{G. Kemungkinan dan Urgensi Relokasi}

Berdasarkan data lapangan yang diperoleh di Papua, diketahui bahwa telah cukup banyak industri yang mengolah kayu merbau, antara lain 9 industri besar (kapasitas $>6000 \mathrm{~m}^{3} /$ tahun) dan 66 industri kecil (kapasitas 6000 m3/tahun) (BSPHH, 2003). Sebagian besar IPKH di Papua saat ini beroperasi dibawah kapasitas. Dari 9 industri besar, 5 perusahaan beroperasi belum optimal karena kekurangan pasokan bahan baku, demikian pula hal ini dialami oleh industri kecil pengolah merbau. Fakta tersebut menunjukkan bahwa permintaan Pemerintah Propinsi Papua agar diberi dispensasi untuk mengekspor kayu merbau dalam bentuk dolok adalah tidak tepat dan rencana Pemerintah merelokasi industri pengolah kayu merbau dari Jawa ke Papua menjadi tidak beralasan untuk dilakukan.

Selain itu, pemberian dispensasi khusus untuk mengekspor dolok merbau, akan mendatangkan berbagai dampak negatif baik bagi masyarakat setempat, industri pengolah kayu maupun pemerintah/negara. Bagi masyarakat setempat, pemberian dispensasi ekspor dolok merbau akan mengakibatkan hilangnya kesempatan untuk memperoleh nilai tambah (nilai tambah berpindah ke negara pengimpor merbau), hilangnya kesempatan memperoleh pekerjaan dan hilangnya kesempatan memperoleh penghasilan dari pengolahan kayu merbau.

Pemberian dispensasi ekspor dolok merbau. dikhawatirkan akan menimbulkan preseden buruk di masa mendatang. Dengan alasan yang dicari-cari, Pemda lain yang potensial menghasilkan suatu jenis kayu (di luar Papua) dapat saja mengikuti Papua untuk meminta dispensasi ekspor dolok kayu yang dimilikinya. Bila hal ini sampai terjadi, maka dapat dibayangkan kesulitan yang akan dihadapi oleh industri pengolah kayu dalam negeri. Dengan pelarangan ekspor kayu bulat saja, setiap tahunnya industri pengolah kayu di Indonesia masih mengalami kekurangan (defisit) kayu sebesar 37,91 juta m³ (Purnama, B.M. et al, 2003).

Negara-negara pengimpor kayu merbau dari Indonesia, akan muncul menjadi pesaing kuat bagi industri pengolah kayu merbau dalam negeri. Sebagai contoh negara China (RRC), bila negara tersebut dapat memperoleh dolok merbau dari Indonesia, industri pengolahan kayu merbau di China lebih mampu menghasilkan produk olahan dengan biaya produksi lebih rendah, sehingga dapat menekan harga jual produknya. Hal ini memungkinkan, karena dari segi teknologi, China telah mampu memproduksi sendiri mesin dan peralatan pengolah kayu. Karena diproduksi sendiri, tentunya biaya investasi pengadaan mesin dan peralatan oleh industri pengolahan kayu di China akan jauh lebih murah dibandingkan dengan di Indonesia. Dari segi sumber daya manusia, tenaga kerja di China terkenal tinggi produktivitasnya, sedangkan produktivitas tenaga kerja di Indonesia lebih rendah. Dari segi bahan pembantu terutama bahan kimia, China telah mampu memproduksi sendiri, sedangkan industri pengolahan kayu di Indonesia masih banyak tergantung kepada bahan kimia impor. 
Bagi pemerintah/negara, pemberian dispensasi ekspor dolok merbau akan menurunkan pendapatan devisa negara karena menurunnya ekspor produk olahan kayu merbau akibat menurunnya pasokan kayu merbau bagi industri dalam negeri dan masuknya pesaing kuat di pasaran internasional. Dalam jangka panjang, pemberian dispensasi ekspor dolok kayu, akan lebih memacu terhadap eksploitasi sumber daya hutan yang berlebihan.

Bila ekspor merbau dalam bentuk dolok tidak beralasan untuk dilakukan, tentunya Pemerintah Pusat berkewajiban untuk mencarikan jalan agar Pemda Papua dapat memanfaatkan potensi kayu merbau yang dimilikinya, tanpa harus mengekspor kayu tersebut. Salah satu cara yang dapat dilakukan adalah terciptanya suatu kegiatan di Papua yang mampu meningkatkan nilai tambah kayu merbau, memperluas lapangan pekerjaan dan memberikan konstribusi pendapatan yang layak bagi penduduk Papua.

Mengingat telah banyaknya IPKH di Papua yang mengolah merbau hanya sampai produk S2S/S4S dan dikirim ke Jawa, dari proses ini nilai tambah yang bisa dinikmati oleh masyarakat masih terbatas. Untuk meningkatkan nilai tambah pemanfaatan kayu merbau yang perlu dilakukan adalah meningkatkan kemampuan IPKH di Papua sehingga mampu mengolah merbau menjadi berbagai finished-product, antara lain dengan me-reengineering mesin-mesin, meningkatkan kemampuan SDM dan membangun sarana-prasarana industri yang memadai.

Hal lain yang perlu diperhatikan adalah bahwa IPKMA/KOPERMAS sebagai pemasok bahan baku bagi IPKH yang menggergaji kayu merbau dengan gergaji rantai (chain saw), sehingga hasilnya berupa balok masih kasar dan harganya relatif murah. Untuk meningkatkan nilai tambah perlu dukungan pemerintah dalam rangka meningkatkan kemampuan IPKMA/KOPERMAS sehingga mampu memproduksi kayu gergajian halus dengan peralatan yang lebih efisien. Selama ini IPKMA/KOPERMAS belum mendapatkan pembinaan yang memadai dari Pemerintah.

\section{KESIMPULAN DAN SARAN}

\section{A. Kesimpulan}

1. Potensi kayu merbau di Papua saat ini sebesar $27.07 \mathrm{~m}^{3} /$ ha untuk pohon berdiameter 20 - 49 $\mathrm{cm}$ dan $33.29 \mathrm{~m}^{3} /$ ha untuk pohon berdiameter $50 \mathrm{~cm}$ up. Potensi tersebut diperkirakan dapat memasok kebutuhan industri di Papua dengan kapasitas ijin $650.565 \mathrm{~m}^{3} /$ tahun untuk jangka waktu $>5$ tahun.

2. Produk olahan kayu dari Papua sebagian besar berupa kayu gergajian dan sedikit berupa S2S/S4S yang dikirim ke Jawa. Sebagian kecil produksi untuk konsumsi lokal, yaitu digunakan sebagai bahan bangunan.

3. Industri pengolah merbau di Papua yang hampir seluruhnya mengkonversi kayu bulat menjadi kayu gergajian dapat ditingkatkan efisiensi dan nilai tambah produknya melalui pembuatan finished product, diversifikasi, dan pemanfaatan limbah.

4. Industri kayu merbau di Papua bekerja di bawah kapasitas sehingga kebijakan untuk mengekspor kayu bulat merbau dari Papua tidak tepat untuk dilakukan.

5. Tidak ada alasan yang kuat untuk melakukan relokasi industri pengolah merbau ke Papua, yang diperlukan adalah peningkatan kemampuan industri di Papua untuk memproduksi finished product. 


\section{B. Saran}

1. Implementasi program restruktutrisasi industri dalan lingkup industri kayu merbau memerlukan data potensi kayu yang akurat. Untuk memastikan besaran potensi kayu merbau di Papua diperlukan rekalkulasi potensi, sehingga tidak menimbulkan mis-interpretasi potensi.

2. Berdasarkan kajian ini, relokasi industri kayu merbau ke Papua bukan merupakan alternatif terbaik dalam restrukturisasi industri, sehingga disarankan untuk tidak dilakukan.

3. Industri kayu merbau dan industri kayu lainnya di Papua memerlukan pembinaan berupa peningkatan kemampuan industri sehingga mampu mengolah bahan baku kayu merbau menjadi produk akhir.

\section{DAFTAR PUSTAKA}

Anonim, 2001. Statistik Dinas Kehutanan Papua. Dinas Kehutanan Propinsi Papua, Jayapura.

2002. Eksekutif Data Strategis Kehutanan 2002, Badan Planologi Kehutanan, Departemen Kehutanan. Jakarta.

, 2003a. Perkembangan pengesahaan RKT 2003. Dinas Kehutanan Propinsi Papua, Jayapura.

2003b. Perkembangan pengesahan RPBI IPKH pada wilayah kerja BSPHH Wilayah XVII Jayapura. Bahan Rakontek BSPHH 2003, Jayapura.

2003c. Laporan produksi kayu bulat perusahaan. Dinas Kehutanan Propinsi Papua, Jayapura.

2003d. Distribusi harga kayu merbau. Unit Pelaksana Teknis Daerah (UPTD) Kehutanan Jayapura

Fretes, Y.D., 2003. Komunikasi pribadi. Conservation International, Jayapura.

Instruksi Presiden Nomor 7 tahun 2002 tentang Strategi Nasional Percepatan Pembangunan Kawasan Timur Indonesia, tanggal 27 Nopember 2002.

Martawijaya, A., I. Kartasujana, Y.I. Mandang, S.A. Prawira dan K. Kadir, 1989. Atlas Kayu Indonesia Jilid II. Badan Penelitian dan Pengembangan Kehutanan, Departemen Kehutanan, Bogor.

Pangkali, L.B., 2003. Komunikasi pribadi. World Wild Fundation, Jayapura.

Purnama, B.M, A. Justianto, R. Tjandrakirana dan K.B. Prihatno, 2003. Produksi Kayu Bulat Indonesia: Potensi dan Permasalahan. Prosiding Diskusi Panel "Menyongsong Industri Perkayuan Yang Lestari”, Kerjasama Puslitbang Sosek Kehutanan, ITTO Project PD 85/01 Rev. 2 (1) dan BRIK. Jakarta.

Rajaar, H.J., 2002. Profil potensi sumber daya hutan di Propinsi Papua. Dinas Kehutanan Papua, Jayapura. 
Soerianegara, I \& Lemmens, R.H.M.J., 2002. Sumber Daya Nabati Asia Tenggara No. 5(1) Pohon Penghasil Kayu Perdagangan Utama. Kerjasama PT Balai Pustaka (Jakarta) Prosea Indonesia (Bogor).

Soewarsono, W., 1963. Penyelidikan pendahuluan tentang sifat fisik dan mekanik kayu Indonesia. Laporan No. 5, Desember 1963. Lembaga Penelitian Hasil Hutan, Deptan \&Agraria. Bogor.

Worembae, K., 2003. Pemberdayaan Koperasi di Bidang Kehutanan. Prosiding RAKERNIS Kehutanan Provinsi Papua Tahun 2003, Dinas Koperasi dan Pengusaha Kecil Menengah Provinsi Papua, Dinas Kehutanan Papua, Jayapura. 